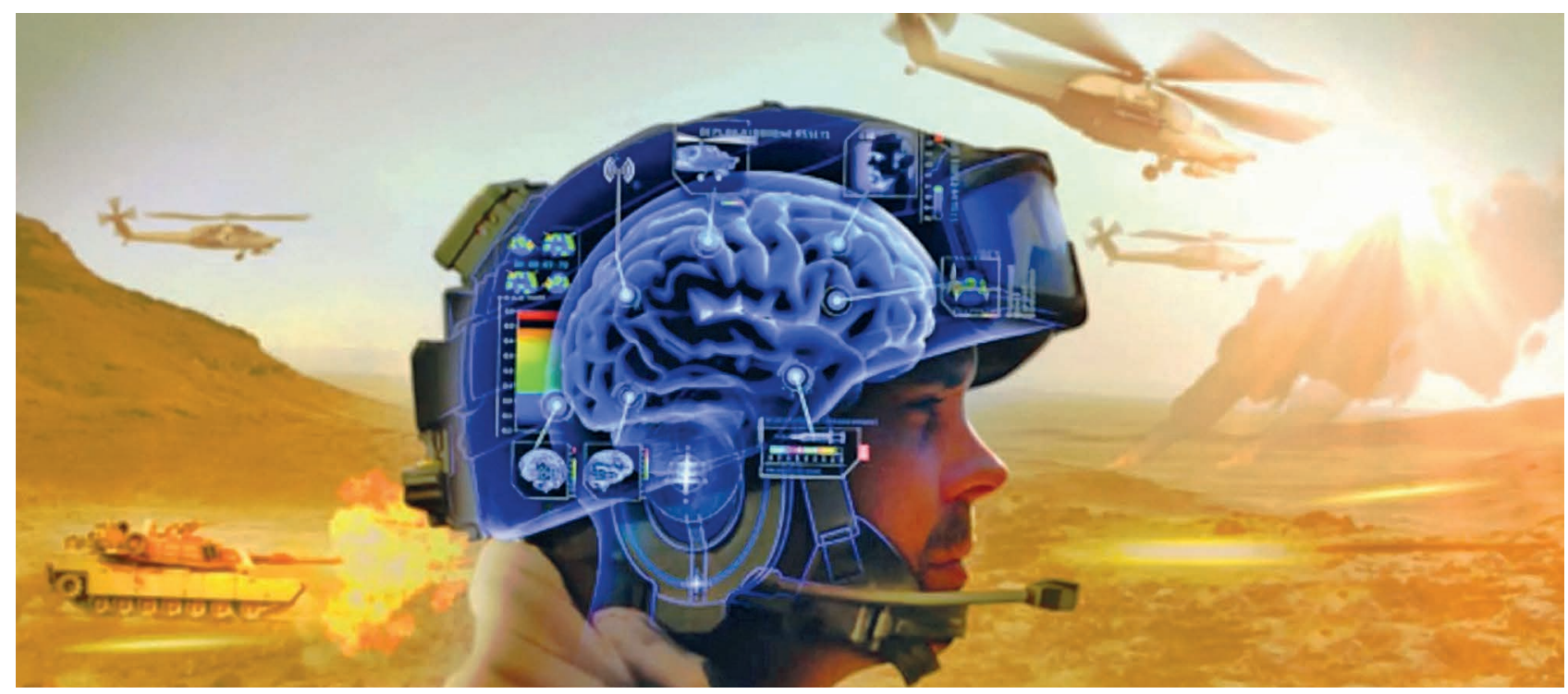

Dr. Hegedüs Ernö* - Szivák Petra**

\title{
A jövő digitális katonája és kognitív képességei - beszámoló a Digital Soldier 2.0 nemzetközi konferenciáról
}

2019. április 30-án „Digital Soldier 2.0 - Fókuszban a katona" címmel, mintegy 400 hazai és külföldi résztvevővel tartott angol nyelvű, nemzetközi tudományos konferenciát a Magyar Honvédség Modernizációs Intézet Budapesten, a Stefánia Palota Honvéd Kulturális Központban. ${ }^{1}$ A konferencián megjelent és előadást tartott, illetve szólt a hallgatósághoz dr. Böröndi Gábor altábornagy, a Magyar Honvédség Parancsnokságának parancsnokhelyettese, Prof. Dr. Szilvássy Zoltán, a Debreceni Egyetem rektora, a Szegedi Tudományegyetemről Tóth László egyetemi docens, a Tudományos és Technológiai Parkok Szövetségének képviseletében Dávid Roland, az ALEAS Simulations Inc.-től Vécsey Zsadány társalapító, a Platypus Institute képviseletében dr. Amy A. Kruse tudományos igazgató, valamint dr. Porkoláb Imre ezredes, a Honvédelmi Minisz- térium, Nemzeti Fegyverzeti lgazgató Kutatás-fejlesztésért és Innovációért Felelős Helyettese.

A konferencia olyan kérdésekre keresett választ, mint például: milyen lesz a jövő hadserege, milyen mértékű együttműködés valósul meg a jövőben a különféle robotokkal és a mesterséges intelligenciával. Lesznek-e majd gondolattal irányított fegyverek és milyen lesz az embergép kapcsolata? Hogyan fejleszthető az emberi elme teljesítőképessége a jövő bonyolult katonai környezetében? Mindeközben a rendezvény időtartama alatt lehetőség nyílt a haderő és a védelmi ipar szereplői által bemutatott modern haditechnikai eszközökből és hadiipari termékekből rendezett kiállítás megtekintésére.

A konferencia kísérő rendezvényén láthatóak voltak olyan high-tech technológiák, mint a HoloLens, VR és AR
ÖSSZEFOGLALÁS: 2019. április 30.-án „Digital Soldier 2.0 - Fókuszban a katona” címmel tartott angol nyelvü, nemzetközi tudományos konferenciát Budapesten, a Stefánia Palota Honvéd Kulturális Központban a Magyar Honvédség Modernizációs Intézete. A rendezvényen neves magyar és külföldi szakemberek előadásai hangzottak el a katonák kognitív fejlesztése témakörében. A konferencia amelyen a szakterület számos elismert szakértőjje tartott előadást - meghatározó jelentőségű volt a Zrínyi 2026 haderófejlesztési program szempontjából is.

KULCSSZAVAK: digitális katona, kognitív képesség fejlesztése, MH Modernizációs Intézet, Zrínyi 2026 haderőfejlesztési program
ABSTRACT: On 30 April 2019, an international scientific conference in English 'Digital Soldier 2.0 - Focus on the Soldier' organized by the Modernisation Institute of the Hungarian Defence Force was held at the Stefánia Palace Cultural Centre. Presentations were made by renowned Hungarian and foreign speakers on cognitive development of soldiers. The conference, which was attended by many recognized experts in the field, was of decisive importance for the Zrínyi 2026 military development program.

KEY WORDS: digital soldier, development of cognitive ability, Modernisation Institute of the Hungarian Defence Force, Zrínyi 2026 Defence and Armed Forces Development Programme

\footnotetext{
* Mérnök alezredes, PhD, Nemzeti Közszolgálati Egyetem/National University of Public Service, ORCID: 0000-0001-8457-5044

** MH Modernizációs Intézet/HDF Modernisation Institute. Haditechnika szerkesztőasszisztens, DOI adminisztrátor. ORCID: 0000-0002-5040-8739
} 
szimulációs képzés-bemutatók, agyi kapacitás-fejlesztés, korszerü fegyverek, drónok és az MH 2. vitéz Bertalan Árpád Különleges Rendeltetésű Dandár statikus bemutatója is.

A konferenciáról a többek között a Haditechnika folyóirat Facebook oldalán kaphatott előzetes híradást - illetve egyúttal regisztrációs lehetőséget is - az érdeklődő szakmai közönség.

\section{A KONFERENCIA ELŐADÁSAI}

Dr. Böröndi Gábor altábornagy, a Magyar Honvédség Parancsnokságának parancsnokhelyettese „Lépéstartás a virtuális generációval - a digitális világ a haza szolgálatában" címú megnyitó előadásában elmondta, hogy a napjainkban zajló rohamos ütemű technikai fejlődés magában hordozza a hadviselés gyökeres átalakulását. Ezekre a kihívásokra válaszul zajlik a Zrínyi 2026 Honvédelmi és Haderő Fejlesztési Program, amelyben kiemelt prioritást kapott a hazai védelmi ipar újjáélesztése és minél szélesebb körű bevonása a fejlesztések végrehajtásába. A korszerű technika és a folyamatosan változó bonyolult helyzetek kezelése szükségessé teszi a katona kognitív fejlesztését is. A konferencia témaválasztása tükrözi a haderő szemléletváltását, amely a korszerű tudományos eredmények ismertetésével, valamint a témakörhöz kapcsolódó kézzelfogható technikai eszközök kiállításával is hangsúlyozza a katona fontosságát a Zrínyi 2026 program során. Olyan hazai és nemzetközi trendek, kutatási eredmények kerülnek bemutatásra a konferencián, amelyeken keresztül egyértelművé válik az $\mathrm{MH}$ elkötelezettsége a katonák kognitív fejlesztésének fontossága érdekében. A konferencián előadott területekhez kapcsolódóan kísérleti projektek indítására törekszik a Magyar Honvédség, amelyek sikere esetén az eredményes területek széles körben bevezetésre kerülhetnek. Nem pusztán csak a haditechnikai eszköz-beszerzések jellemzik a Zrínyi 2026 programot, hanem a Magyar Honvédség teljes megújulása is.

Dr. Tóth László, a Szegedi Tudományegyetem egyetemi docense „A mély neuronhálók beszédtechnológiai alkalmazásai" címmel tartott előadást. A kutató az MTA-SZTE Mesterséges Intelligencia Kutatócsoport tagja. Tóth László előadásában elmondta, hogy a mesterséges intelligencia gyakorlati alkalmazhatóságában jelentős javulást hozott a mély tanulási módszerek, az ún. mély neuronhálók bevezetése. „A környezetfüggő mély neuronhálós akusztikus modellek gyors adaptációja különösen kemény kihívás, mivel egy kis méretű adaptációs mintában a környezetfüggő állapotok többségére nincs tanító példa. Nemrégiben egy olyan új mély neuronhálós tanítási séma bukkant fel, amely a hálózatot egyszerre tanítja környezetfüggő és környezetfüggetlen példákon. Ez az ún. multi-taszk technológia felveti annak a nagyon egyszerű adaptációs módszernek a lehetőségét, hogy az adaptáció során csak környezetfüggetlen címkéken tanítsunk. Ez a módszer ... kombinálható egy KL-divergencia alapú regularizációs technikával."2 A szakember előadásában bemutatta a mesterséges intelligencia, a gépi tanulás és a mély tanulás kapcsolatát, valamint hogy mi vezetett a mesterséges intelligencia jelenlegi forradalmához. Ezután ismertette a beszédtechnológia fő alkalmazási területeit, megvizsgálva, hogy ezeken a területeken milyen új eredményeket hozott a mély tanulási technológia bevezetése. Beszélt a gépi beszédfelismerés, beszédelőállítás jelenlegi helyzetéről, valamint a beszédből kinyerhető egyéb, ún. paralingvisztikai információkról, amelyeknek akár kriminalisztikai, illetve katonai alkalmazá-

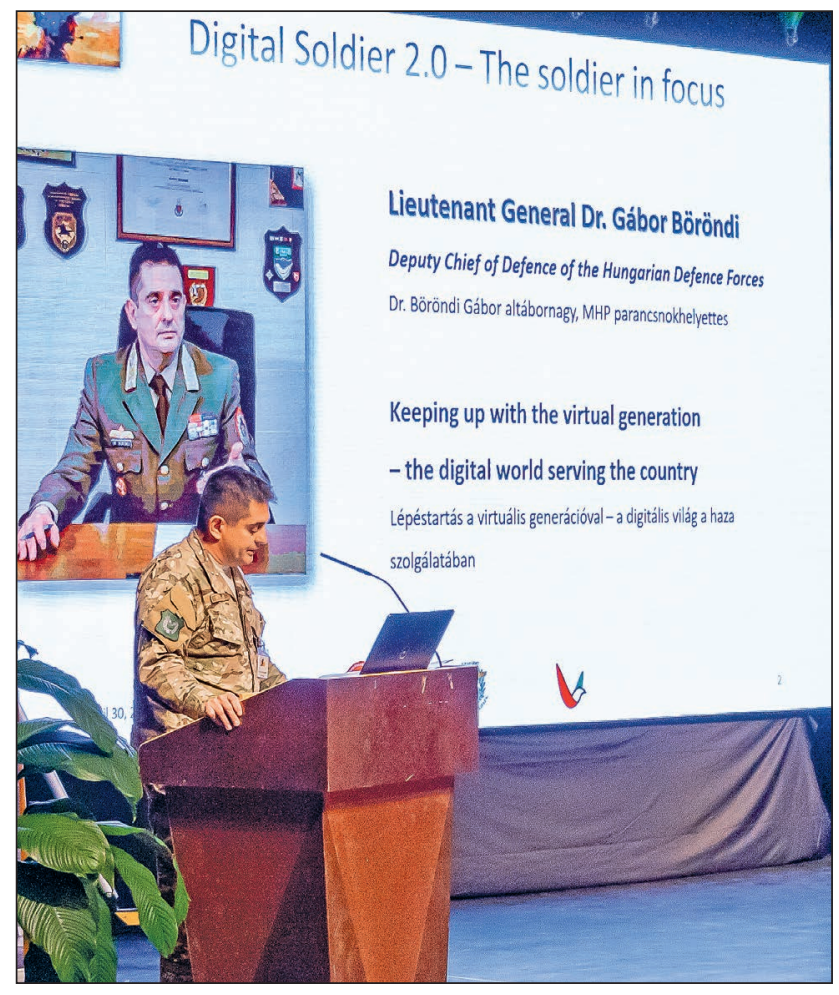

1. ábra. Dr. Böröndi Gábor altábornagy, a Magyar

Honvédség Parancsnokságának parancsnokhelyettese a konferencián (Fotó: M. B.)

\section{2. ábra. A digitális katona technikai eszközei a sisakon}

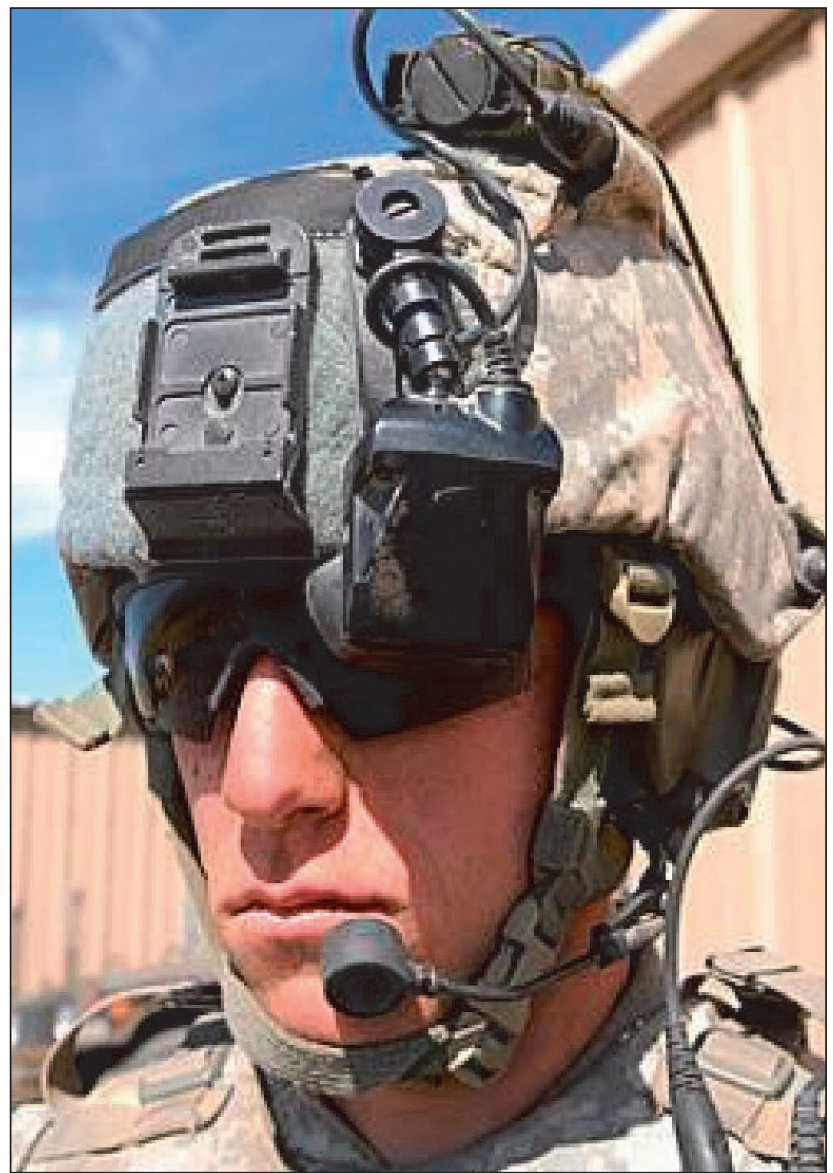


sa is lehetséges. Szintén jól alkalmazható katonai környezetben - erős háttérzajban - a beszéd gépi felismerése.

Dr. Amy A. Kruse, az Arlingtoni Platypus Institute tudományos igazgatója „Soldier 2.0: A katonai teljesítmény neurotechnológiai fejlesztése" című előadásában ismertette az intézeténél, illetve a DARPA-nál (Defense Advanced Research Projects Agency - Fejlett Védelmi Kutatási Projektek Ügynöksége) e téren utóbbi években felhalmozódott tapasztalatok publikus részét. Dr. Amy A. Kruse az Illinois-i Egyetemen szerezte meg doktori fokozatát az emberi agy kognitív teljesítőképessége és az emberi viselkedés tárgykörében. 2005 és 2010 között a DARPA programmenedzsere, 2010 és 2015 között innovációs igazgatója, 2015 óta alelnöke. Kutatási területe az emberi agy adaptációs képessége dinamikusan fejlődő technológiai környezetben, illetve a kognitív képességek fejlesztésének lehetősége. Dr. Amy A. Kruse, előadásában az alábbi kérdésekre kereste a választ: növelhető-e az emberi memória kapacitása, az agy teljesítőképessége, illetve a koncentrálóképesség és a döntéshozatal sebessége? Milyen módszerek, berendezések és eljárások alkalmasak erre? Katonai alkalmazás során nemcsak a katona kognitív képességei képezik a kutatás tárgyát, hanem a katonák egy csoportjának - például egy különleges műveleti csoportnak - az együttműködése is. Sőt, a kutatások homlokterébe került az emberi és a mesterséges intelligencia együttműködésének kérdése, az emberi agy és a robotok közötti együttműködés korlátainak vizsgálata, hatékonyságának fokozása, illetve az ember- és robotcsoportok közötti együttműködés lehetőségeinek vizsgálata is. Az „operatív idegtudomány” és a neurotechnológia előrehaladásának bemutatásával ez az előadás a hadsereg teljesítményének javításáról szóló gondolatokat motiválta. A DARPA a Human 2.0, (Ember 2.0) a Warfighter 2.0 (Katona 2.0) és az Athlete 2.0 kognitív fejlesztési programokat futtatta le e kérdések megválaszolása érdekében. ${ }^{3}$ Ezek közül az előadó részletesen bemutatta az „Ember 2.0” koncepciót, különös hangsúlyt fektetve a „Katona 2.0” koncepcióra. A digitális technológia

3. ábra. A DARPA Warfighter 2.0 program során mesterlövészek agyi funkcióit vizsgálták. Egy fejre helyezett berendezéssel növelték találati pontosságukat

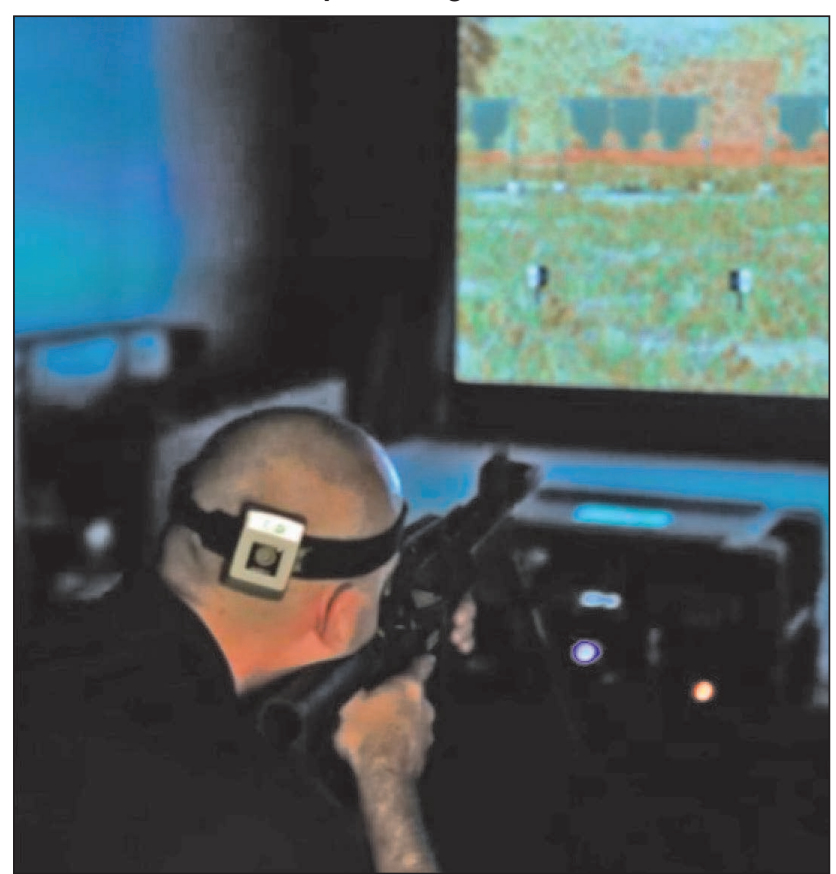

gyorsabban fejlődik, mint az emberi feldolgozóképesség, és egy ponton túl ezt a problémát csak az emberi agy kognitív képességeinek fejlesztésével lehet megoldani. Az amerikai tudós részleteiben tárgyalta az emberi képességek „korszerűsítésének” néhány közeli megvalósítási lehetőségét.

Az Egyesült Államok haderejének különleges műveleti parancsnoksága (U.S. Special Operations Command) már tesztelte is katonáin az új kognitív teljesítménynövelő eljárásokat. A tesztek során a katonák fejére kognitív teljesítményfokozó berendezést helyeztek. Mesterlövészek teljesítőképességét és agyi funkcióit vizsgálták, majd egy fejre helyezett berendezéssel eredményes kísérleteket végeztek teljesítőképességük, találati pontosságuk növelésére. A szellemi teljesítmény gépi növelésének lehetőségeiről a szakember elmondta, hogy tapasztalataik alapján már néhány hetes visszacsatolásos kognitív fejlesztés eredményre vezet. Egy hathetes program során 12\%-os kognitív képességjavulást értek el. Szólt az ember-gép együttműködés vizsgálatának, fejlesztésének fontosságáról is. Ehhez kapcsolódóan, a DARPA a Human 2.0 programot kiegészítette a mesterséges intelligencia (Al - Artifical Intelligence) vizsgálatával, létrehozva a Centaur programot.

Vécsey Zsadány a kaliforniai ALEAS Simulations, Inc. képviseletében tartotta meg „Vezetésfejlesztés szimulációs alapokon - Egy Navy SEAL fejlesztő projekt tanulságai" című előadását, amelynek középpontjában egy Flow-alapú vezetésfejlesztő szimulációs program áll. A szimulációs és virtuális valóság technológiák jelentős sebességgel fejlődnek, és ma már a haderő mellet az üzleti szektor is szívesen alkalmazza ezeket az eszközöket. A komplex rendszerek - mint vezetési dilemma - vizsgálata a gyakorlati életben meglehetősen bonyolult feladat. A szimuláció egy olyan elemző eszköz, amely lehetővé teszi ellenőrzött kísérletek elvégzését. A „komoly játékok” (serious games) olyan számítógépes (jellemzően online) alkalmazások, amelyek videójáték mechanizmusokat felhasználva közvetítenek célzott információkat (ismeretet), segítenek a tanulás tárgyát képző jelenség megismerésében, és a megoldási folyamat begyakorlásában. Ennek megfelelően abban különböznek a klasszikus digitális játékoktól, hogy céljuk nem elsősorban a felhasználó szórakoztatása, hanem a megértési és tanulási folyamat támogatása. Az előadás bemutatta, miként alkalmazzák a FLIGBY online vezetésfejlesztő szimulációt (interaktív mozi formátumban) a Navy SEAL parancsnokok képzési programjában, és milyen tanulságokkal jár a katonai felhasználók számára egy alapvetően civil problémamezőt bemutató szimuláció. A „FLIGBY” a „FLOW is Good Business” elnevezésű vezetésfejlesztő szimuláció rövidítése, amelyet Csíkszentmihályi Mihály professzorral (a Flow-elmélet atyjával) fejlesztett az ALEAS Simulations csapata. ${ }^{4}$ Dr. Csíkszentmihályi Mihály pszichológus 1975-ben definiálta a Flow-élményt. Ez az elmélet a hatékony munkavégzés pszichés körülményeit vizsgálja, mivel az alámerülés, elmélyedés és áramlás (flow) előnyös hatásait az egyén akkor érzi, amikor átélten leköti magát elsődleges tevékenységeivel. Csíkszentmihályi professzor együttműködött az ALEAS Simulations csapatával „Jó üzlet" című Flow-könyvének szimulációs feldolgozására. ${ }^{5}$ A professzor pozitív pszichológia területén megfogalmazott elmélete nyomán a magyar - amerikai ALEAS cég olyan szimulációs rendszert fejlesztett ki és müködtet egyre nagyobb sikerrel, amely hidat teremt az élet értelmének tartott boldogság (flow-élmény), az üzleti profit, valamint a környezeti és társadalmi alapokon nyugvó fenntarthatóság között. A szimulációs program hatékonyabb vezetői attitűdök és módszerek oktatására alkalmas, a vissza- 
csatolás alkalmazása és a kompetencia alapú mérések végzésének lehetősége jellemzi. A FLIGBY program helyet kapott a Navy SEAL különleges műveleti erő felkészítő programjában is. Alkalmazása során mérték az információfeldolgozás, illetve a feladatmegoldás képességének változását.

Dr. Dávid Roland - az Innoria Kft. társalapítója és ügyvezetője - a Tudományos és Technológiai Parkok Szövetségének képviseletében „Coherence \& Team Flow: egyéni és csapatszintű képességfejlesztő EEG technológiák” címmel tartott előadást. Elmondta, hogy neuroscience alapú rendszereinkkel az agyhullámokat közvetlenül az agyról vételezik, amelyhez EEG technológiát használnak. Szakértőik alkották meg azt az egyedülálló szoftvert, amely képes a nyers jelekből lemodellezni az agyféltekék pontos és valós idejű működését, és ezt vizuálisan a felhasználó elé tárni. Az egymásra épülő rendszerek az egyéni mentális felkészülés (Coherence) és a csapatszintű mentális összehangoltság (Team Flow) megteremtésére is alkalmasak. A kiértékelések alapján a tréningek előre megtervezhetők. Rendszerük beépített képzési csomagjaival az agyat - mint egy izmot - edzik. A felhasználó stresszhelyzetben képessé válik érzelmeinek kontrollállására, a teljesen ellazult pihenés állapotára, a rekreációs idő csökkenésére, a minőségi döntéshozatalra, fejlődik az információbefogadási képessége, a memóriája, a figyelem hosszú távon fenntarthatóvá válik és megnő a tudati fókusz. A csapatszintű képességfejlesztés pillérei: mentális állóképesség fejlesztése, csapaton belüli kontextus-elemzés és korrelációs analízis, mentális teljesítményelemzés. Elhangzott, hogy Michelisz Norbert autóversenyző sikerrel alkalmazta az eljárást versenyfelkészülése során. Az előadás második felében a gyakorlatban mutatták be egy team tagjai között a szoftverükkel létrehozható agyi szinkronitást. Az előadó jelezte, hogy jövőbeni innovációs tevékenységüket a Várpalota Tudományos és Technológiai Park keretei között folytatják majd.

Dr. Porkoláb Imre ezredes, a Honvédelmi Minisztérium, Nemzeti Fegyverzeti Igazgató Kutatás-fejlesztésért és Innovációért Felelős Helyettese „Küldetés alapú vezetés 2.0 - Miért szükséges a digitális transzformáció emberi aspektusaira koncentrálni?" címmel tartotta meg előadását. A kutató több éve foglalkozik az előadásának tárgyát képező területtel. ${ }^{6}$ Dr. Porkoláb ezredes ismertette, hogy mit tanulhatnak a kutatók az elit katonáktól a döntéshozatali folyamatokról, illetve hogy hogyan érhetünk el kimagasló teljesítményt hosszú időn keresztül. Elemezte azt is, hogy mit jelent a vezetés-irányítás a mesterséges intelligencia korában, illetve hogy miért elengedhetetlen, hogy elsősorban a digitális átalakulás emberi aspektusára összpontosítsunk. Az ezredfordulótól ugyanis a hierarchikus szervezeti struktúrák kezdték elveszíteni versenyelőnyüket. A vezetők az új évezredben arra lettek figyelmesek, hogy a bürokratikus szervezeti formák egyre nehezebben képesek megbirkózni a sokkal agilisabb, gyorsabb döntéshozatali folyamatokat futtató rugalmas szervezetekkel, és nem képesek a megváltozott környezeti viszonyok között tartós versenyelőnyt fenntartani tradicionális módszerekkel. Emiatt felértékelődött a magas szinten képzett szakértők hálózatszerű munkavégzése a korszerű szervezeteknél, ami gyorsabb és rugalmasabb működést tesz lehetővé. Az innováció és a szervezetek vezetése területén egyaránt fontos, hogy a tájékozódási-értékelési-döntési ciklus sebességét növelni kell, ami viszont további követelményeket támaszt a munkavégzők kognitív képességeivel szemben. Napjaink egyik legmeghatározóbb kihívása, hogy a digitális transzformáció sebességét nem képes követni az emberi elme, ezért is elkerülhetetlen a kognitív fejlesztés. A tudás- alapú személyi képességek fejlesztése mellett napjainkban előtérbe kell kerülnie a konstruktív tudatállapot fejlesztésének (pl. flow, ill. csoportban agyi szinkronitás), mivel a hatékony munkavégzésre vonatkozó mutatók szerény értéket mutatnak (csak a munkavégzők 11-23\%-a konstruktív a munkavégzésben).

Prof. Dr. Szilvássy Zoltán a Debreceni Tudományegyetem rektora „Tájékozódás és rövid távú memória” címmel tartott előadását. Szilvássy professzor az orvostudomány kandidátusa. Kutatási területei a gasztrointesztinális endokrinológia, inzulintermelés, szenzorosneurofarmakológia, illetve a szív iszkémiás adaptációja. A professzor 2001-ben a Magyar Tudományos Akadémia doktora lett. A profeszszor ismertette a kurkumával kapcsolatos legújabb kísérleti eredményeket. A kurkumin csökkenti az inzulinrezisztenciát, indirekt módon hatással van az idegrendszer működésére is. Az előadó Szolcsányi János professzor munkásságára is hivatkozott, aki felfedezte a szenzoros-efferens reflex nélkül működő kettősfunkciójú idegszabályozó rendszert. A kurkuma az agyműködésre - ezen belül a memóriára - is jótékony hatással van, az Alzheimer-kór kialakulásának esélyét is csökkenti. A rövid távú memória teljesítménymutatói összefüggenek a tájékozódóképességgel is.

\section{ÉLEN JÁRÓ TECHNOLÓGIÁK}

A konferenciát kísérő kiállításon láthatóak voltak többek között olyan high-tech technológiák is, mint a HoloLens. A HoloLens egy olyan térbeli vizuális szimulációra alkalmas headset, ami a „kiterjesztett valóságra” épít. Ez rendkívül hasznos lehet a tervezőmérnököknek, illetve az egészségügyben, összetett rendszerek vizsgálatakor. A Microsoft érintéssel és szemkövetéssel is biztosítja az interakciót, elég kinyúlnunk magunk elé, és megérintenünk azt a helyet, ahol az interaktív hologram megjelenik számunkra.

De a HoloLens jelentős előrelépést jelenthet a katonai kiképzésben is. Az USA hadereje épületharc kiképzésben alkalmazza a HoloLens rendszert.

„Coherence \& Team Flow egyéni és csapatszintű képességfejlesztő EEG technológiák" bemutatására vállalkozott az Innoria Kft. A Neuroscience alapú rendszerekkel az agyhullámokat vételezik és elemzik. Az egymásra épülő rendszerek az egyéni mentális felkészülés (Coherence) és a csapatszintű mentális összehangoltság (Team Flow) megteremtésére alkalmasak. A Coherence rendszer segítségével a felhasználók a Team Flow Measure által kimutatott hiányosságaikat nagyban javíthatják. Ehhez az EEG technológiát és saját szoftvereiket használják. A cég szakértőik alkották meg azt az egyedülálló szoftvert, amely képes a nyers jelekből lemodellezni az agyféltekék és a tudatállapotok pontos és valós idejü működését, és ezt vizuálisan a felhasználó elé tárni. A szoftverbe modulárisan elkülönített leckesorokat építettek, amelyek mindegyike

4. ábra. HoloLens alkalmazása az U.S. Army épületharc kiképzésében

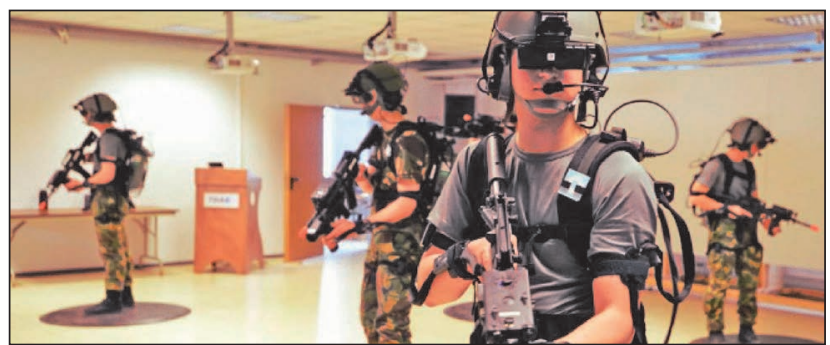




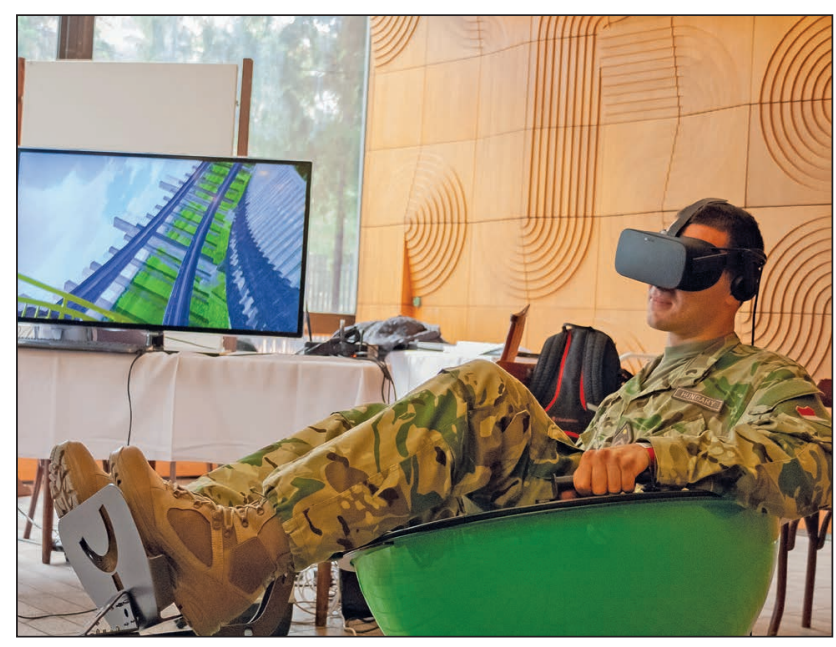

5. ábra. Yaw VR mozgásszimulátor, szemüveggel. A berendezés komplex mozgásformák élethű szimulációjára képes (Fotó: M. B.)

egy adott agyhullámhoz kapcsolható feladatkör fejlesztésére alkalmas. A felhasználó elvégzi a számára előírt egyedi gyakorlatokat, és ezáltal az agyat - mint egy izmot - hozzászoktatja bizonyos állapotokhoz.

A Yaw VR névre keresztelt mozgásszimulátor lényege egy mobil beülö-félgömb, amelyhez egy lábtartó is tartozik. A VR-szemüvegben megjelenő szimulációnak megfelelően, elektromotorok mozgatják a félgömbben ülő felhasználót.

A szakkiállítás egyik legérdekfeszítőbb része a hazai gyártású, közepes kategóriájú helikopter UAV-k (Unmanned Aerial Vehicle - személyzet nélküli légi járművek) megjelenése volt. A harctéri UAV üzemeltetés egyik legérzékenyebb része a fel- és leszállás kérdésköre, amelyre - szerkezetüknél fogva - hatékony megoldást kínálnak a különféle VTOL (Vertical Take Off and Landing - függőleges fel- és leszállás) képességű helikopter-UAV-k. A közepes kategória már megfelelő teheremelő képességgel rendelkezik ahhoz, hogy valóban hatékony felderítőrendszereket emeljen fel a levegőbe, és azokat képes is megfelelő hatótávolságra eljuttatni.

A Rotors \& Cams Kft. UC-2 típusjelzésű helikopter-UAVje a NATO Single Fuel Concept (STANAG 1135) előírásnak megfelelően Jet A-1 (kerozin) üzemü, gázturbina-meghajtású repülőeszköz. Az üzemanyagtartályában hordozott 12 liter mintegy 1 óra repülést tesz lehetővé $50 \mathrm{~km}$ /óra sebességgel. A 11 LE teljesítményű, tengelyteljesítményt adó gázturbina a helikopter orr-részében helyezkedik el. A heli-

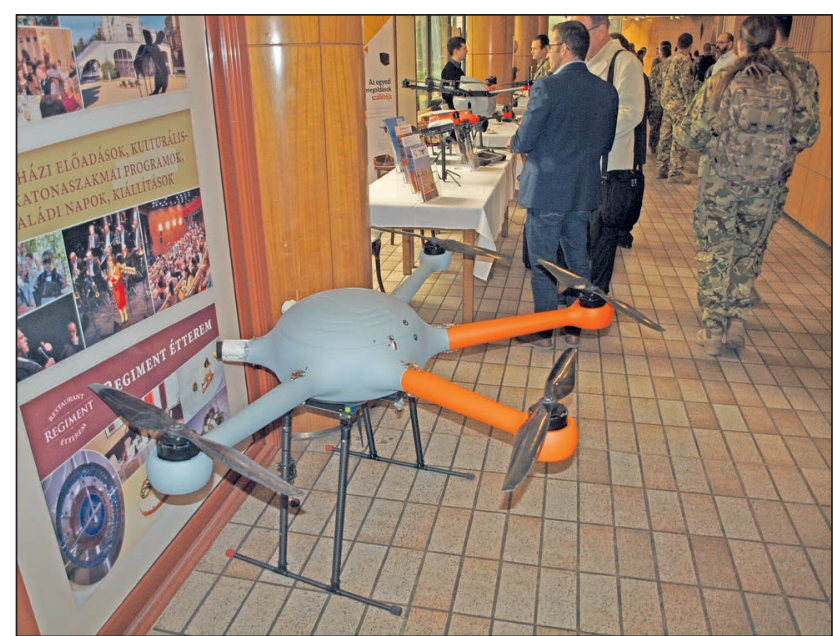

7. ábra. Hazai fejlesztésű, Gigarotor-6 típusjelzésú villamos hajtású helikopter-UAV (a két hátsó rotortartó konzol leszerelt állapotban van) (Fotó: Sz. A.)

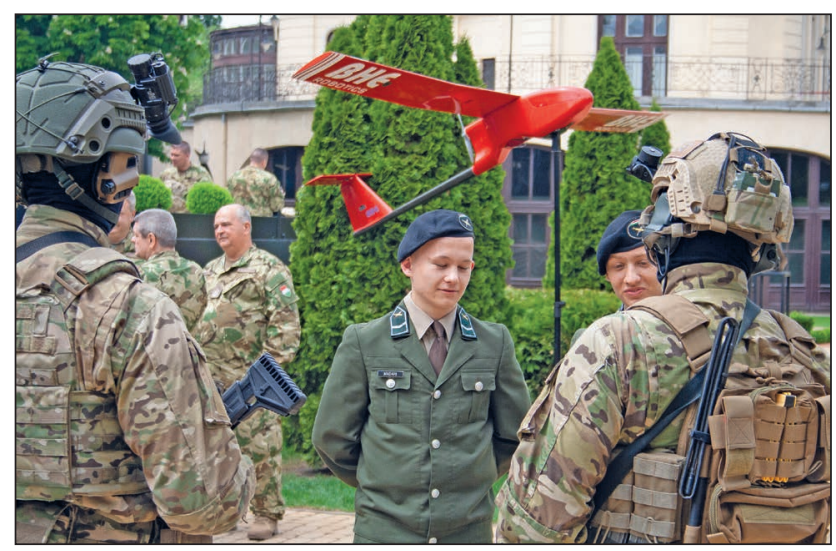

8. ábra. A BHE Robotics Hungary BXAP15 típusjelzésū, pilóta nélküli repülőgépe. Előtérben az MH 2. vitéz Bertalan Arpád Különleges Rendeltetésű Dandár katonái, kevlár sisakra szerelt éjjellátó készülékkel, kerámiabetétes repeszálló mellényben (Fotó: M. B.)

kopter szerkezeti tömege $21 \mathrm{~kg}$, maximális felszálló tömege $37 \mathrm{~kg}$. A törzs alatt $5 \mathrm{~kg}$ tömegű felderítő-berendezés függeszthető. A rotorátmérő $2,5 \mathrm{~m}$. A helikopter GPS és GLONASS navigációval, illetve digitális iránytűvel, inerciális mérőrendszerrel és barometrikus magasságmérővel egy-

6. ábra. A hazai fejlesztésű, UC-2 típusjelzésű gázturbinás helikopter-UAV (b jelű fotó: M. B.)

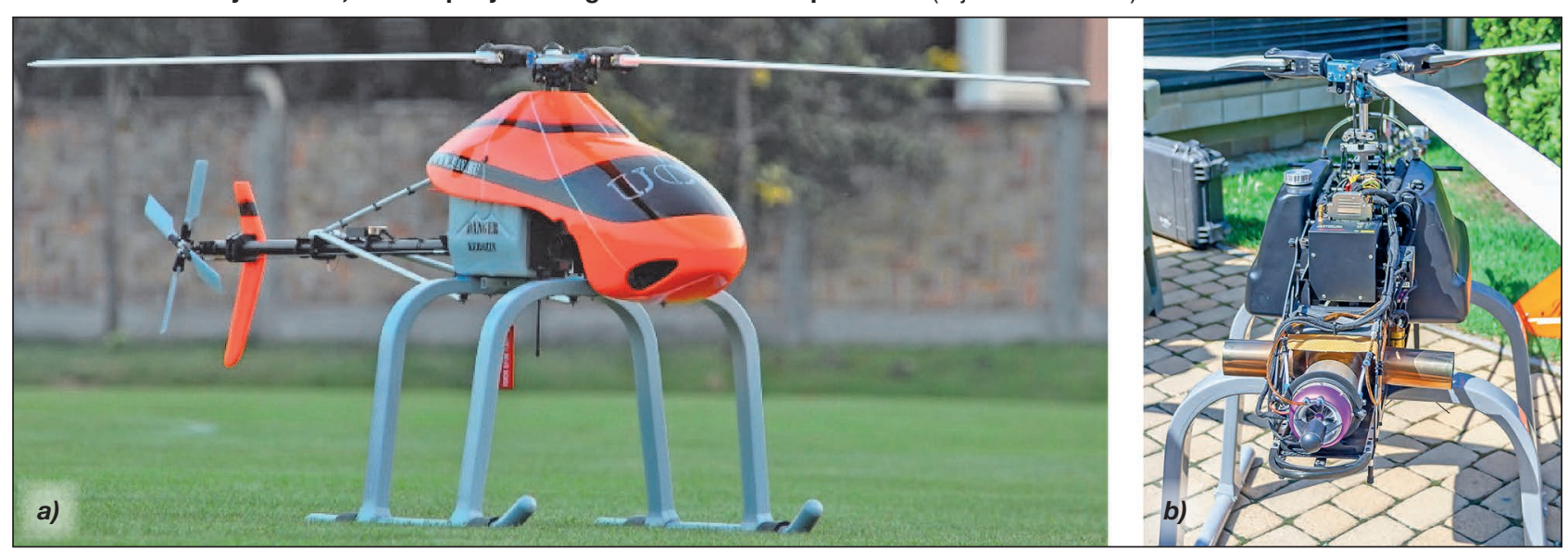




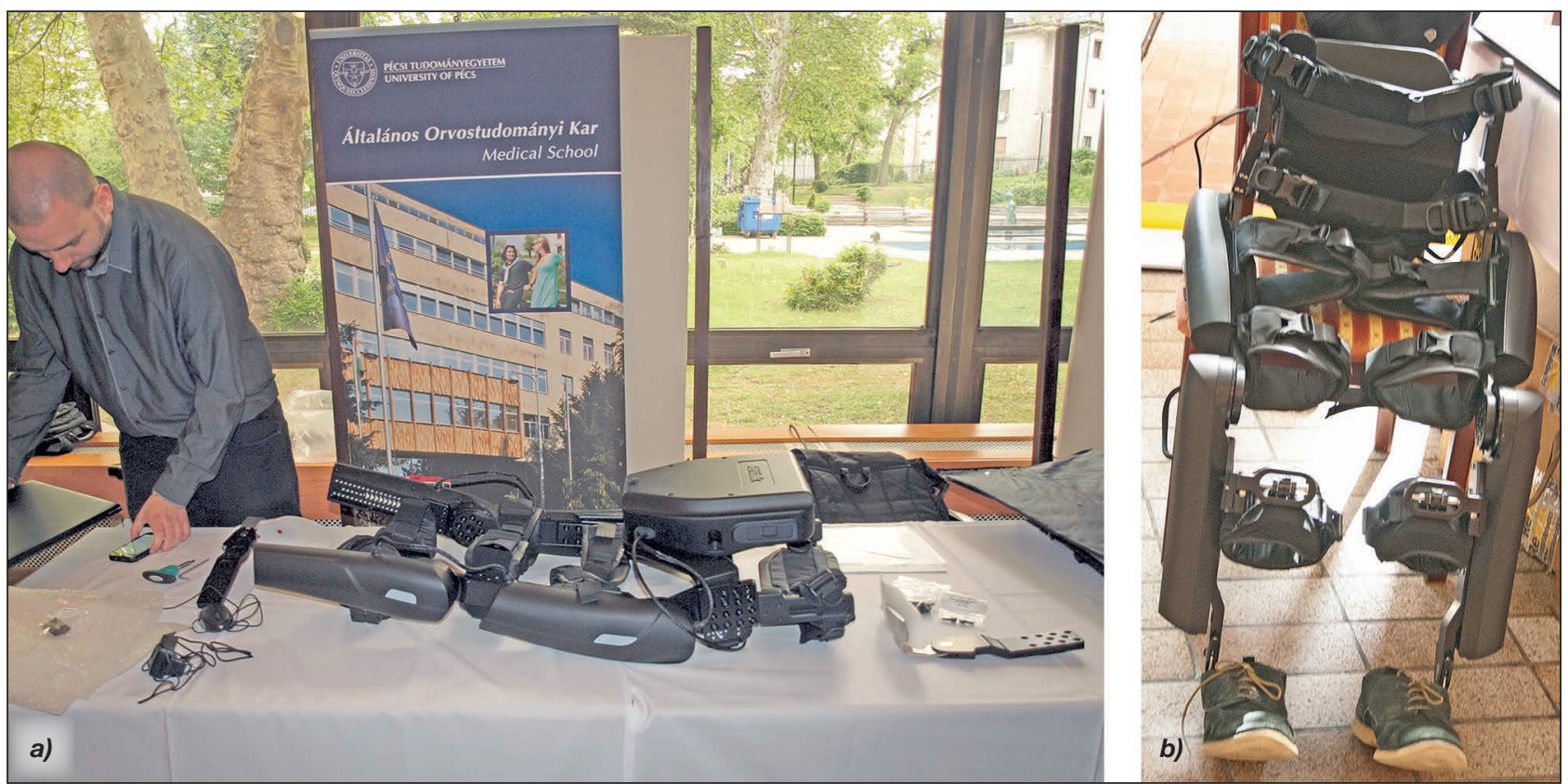

9. ábra. Pécsi Tudományegyetem Általános Orvostudományi Kar által kiálított ReWalk P 6.0. típusú exoskeleton összecsukva, valamint beüzemelve (Fotók: Sz. A., M. B.)

aránt rendelkezik. Dugattyús motorral szerelt változatával a repülési idő 3 órára növelhető.

A Rotors \& Cams Kft. Gigarotor-6 típusjelzésű helikopterUAV-je hatrotoros, elektromos meghajtású repülőeszköz. A 2200 Wh kapacitású Lítium-Polimer akkumulátor mintegy 45 perc repülést tesz lehetővé. A hat darab, egyenként 2,5 LE teljesítményű villamos motor sugárirányú konzolokon helyezkedik el. A helikopter törzs alatt függeszthető hasznos terhe $12 \mathrm{~kg}$ tömegü felderítő-berendezés. SRD irányítással és telemetriás rádióval rendelkezik, képes BVLOS üzemre is.

A BHE Robotics Hungary a BXAP15 típusjelzésű, pilóta nélküli repülőeszközét - UAV repülőgépét - egy rövidfilm vetítésével mutatták be a konferencia előadásai között. A BHE Robotics Hungary Kft. drónja egy jelentősebb infrastruktúrát nem igénylő, pilóta nélküli felderítőgép. A 12 kg szerkezeti tömegű repülőgép üveg- és szénszálas kompozit műanyagból készül, meghajtásáról egy 4,2 kW teljesítményű elektromotor gondoskodik. A drón $5 \mathrm{~kg}$ hasznos terhet képes magával vinni. Hosszúsága 1,7 méter, szárnyfesztávolsága 3,7 méter. A felszállás történhet kerekekről, vagy katapult segítségével. Az akkumulátor másfél óráig képes a levegőben tartani a gépet. A vezérlőegység hatósugara $30 \mathrm{~km}$, de akár $150 \mathrm{~km}$-ig is fejleszthető. Felszerelhető egy nagy felbontású, stabilizált platformon lévő 35-szörös optikai zoommal rendelkező kamerával, továbbá opcionális CBRN analitikai szenzor kiegészítőkkel. A fedélzeti adatrögzítés lehetősége mellett a terjedési viszonyokhoz alkalmazkodó, védett, titkosított mikrohullámú adatátvitel jellemzi a BHE UAV-t.

A Pécsi Tudományegyetem Általános Orvostudományi Kar delegációja élen járó technológiák felvonultatásával vett részt a szakmai kiállításon. A kiállításon a PTE 3D Központ, és a PTE Szimulációs Oktatási Központ mutatta be VR technológiai fejlesztéseit, valamint kiállították a „Neurorehabilitációs és ember-gép kapcsolat" projektben használt ReWalk exoskeletonokat is. A humán exoskeletonok (mesterséges külső vázak) alkalmazásának célja elsősorban az emberi erő fokozása, a képességek kiterjesztése. Napjainkban az exoskeletonok széleskörű elterjedése még várat magára, részben a technológiai megoldások - jövőben várhatóan áthidalható - korlátai miatt. A kiállított eszköz egy alsó végtagi aktív humán exoskeleton. Típusa ReWalk P 6.0. A Pécsi Tudományegyetem Általános Orvostudományi Kar multidiszciplináris fejlesztőcsapatának két tagja a NATO "Integration of the Exoskeletons in the Battlefield" (NATO OED COE) munkacsoportjának tagja. Emellett bemutatták a CAE Engineering Kft.-vel közös VR (Virtual Reality) területen végzett közös fejlesztésüket is.

Ôsszességében elmondható, hogy az innováció nem csupán a technológiai területen fontos, hanem az emberi erőforrás fejlesztése területén is. Amellett, hogy a konferencia a katonákra fókuszált, az előadásokban elhangzó megoldások részben vagy egészben alkalmazhatók a mindennapi élet más régióiban, a kiterjesztett védelmi és biztonsági szféra, valamint az ipar és az oktatás számos területén is.

\section{FORRÁsOK}

1 Draveczki - Ury Ádám: Digitális világ a haza szolgálatában. honvedelem.hu/cikk/115777 [2019. 05. 07.]

2 Tóth László, Gosztolya Gábor: Mély neuronhálós akusztikus modellek gyorsadaptációja multi-taszk tanítással. In: Tanács Attila, Varga Viktor, Vincze Veronika: XII. Magyar Számítógépes Nyelvészeti Konferencia (MSZNY 2016). Szegedi Tudományegyetem, Szeged, Magyarország. (2016) pp. 154-162.

3 Patricia Kime: Engineering Supersoldiers: Boost in lethality may come from within. Association of the United States Army. www. ausa.org/articles 2018.11.24.

4 Csíkszentmihányi Mihály: FLOW - Az áramlat pszichológiája, Akadémiai Kiadó Budapest, 2001.

5 Csíkszentmihályi Mihály: Jó üzlet - Vezetés, áramlat és az élet keresése, Lexecon Kiadó Győr, 2009.

6 Porkoláb Imre: Szervezeti innováció a Magyar Honvédségben: az ember-gép szimbiózisa a stratégiaelméletek tükrében. Haditechnika, 2019. évi 1. szám. DOI: 10.23713/HT.53.1.01 és Porkoláb, Imre: Az innováció hatása a hadviselésre. Hadtudomány, 26: 1-2 pp. 19-28., 10 p. (2016) DOI: 10.17047/HADTUD.2016.26.1-2.19, illetve Porkoláb, Imre: Szervezeti adaptáció a Magyar Honvédségben: küldetésalapú vezetés 2.0 a digitális transzformáció korában. Honvédségi Szemle 147: 1 pp. 3-12., 10 p. (2019). 